\title{
Teaching Civics And Instilling Democratic Values In Israeli High School Students: The Duality Of National And Universal Aspects
}

Nitza Davidovitch, Ariel University, Israel

Dan Soen, Ariel University, Israel

\begin{abstract}
Civic studies in Israel and elsewhere are unlike any other school subject. This course of study has a higher purpose - to transform students into good citizens. In contrast to other core subjects, civics, in essence, strives to realize ethical goals. While other subjects perceive the instilling of values as a secondary outcome, in civics the ultimate goal is to teach values. In Israel, civic studies are currently a compulsory subject for high school students and they are required to learn, know, and understand essential values, principles, and characteristics of Jewish Israeli democracy (since Israel is defined as a Jewish Democratic State). The operational objective of this process is to teach good citizenship and proper involvement in public life.

In the current study, the authors examined to what degree students assimilate these values in practice. For this purpose, the authors administered a questionnaire measuring views on values. It consisted of 16 items on the significance of various values, ranging from the national to the universal. The questionnaire was administered to over 1,300 students at public high schools. In addition, the authors also administered the questionnaire to about 260 teenagers active in a youth movement, with the aim of comparing the value mix of the two populations. Research findings indicated that both groups placed universal values highest, followed by values of self-realization, Zionism, and Judaism, respectively. Research conclusions show a compatibility between the significance accorded to these values in the curriculum and the significance attributed to them by students.
\end{abstract}

Keywords: Civic Studies; Values; Democracy

\section{INTRODUCTION}

( $\mathrm{n}$ the 1990s, civic studies began occupying a significant place in national life due to a worldwide renewal of interest in citizenship. Many countries - mostly developed countries, but also some in the developing world - have come to understand the significance of teaching civics in light of accelerated social, economic, and cultural globalization, which creates myriad national challenges, including the need to cope with the disappearance of "social togetherness" and the belief in a "common good" (Metzer \& Rosen, 2009). A new interest in the concept of civics has been discerned, sparked by a combination of events and trends throughout the world, including perceptions of rising voter apathy, resurgence of nationalist movements, the impact of global forces on local social traditions, the pressures created by increasingly multicultural societies, and the decline in voluntarism in community activities (Prior, 2006). These events have led, among other consequences, to a challenge of western liberal views of democracy and to a view of citizenship as problematic and contestable (Ichilov, 1990; Gilbert, 1996; Hannam, 1999; Prior, 1999, 2006).

On the whole, though, one should note that the concept of "civics", forged in modern times in the context of democracy, nationalism, and the nation state, fundamentally defines citizens' obligations and rights, while forming the basis of their collective identity (Ichilov, 2001). Scholars present various conceptions of the nature of 
citizenship. For example, Marshall (1952), one of the first scholars in this field, perceived citizenship as a mix of civil, political, and social components. Cairns (1999) described citizenship as a combination of lateral and vertical elements - identification with other citizens (lateral) and the sense of belonging (vertical). Heather (1990) sees citizenship as a super-identity uniting all of one's identities and overcoming their factious force. Citizenship may also be interpreted as describing one's state of belonging to a country, society, or community, and carrying diverse rights and obligations. This is essentially a passive outlook, as it assumes that one is awarded citizenship without intentionally striving for it. In this context, members of the Kremnitzer Committee ${ }^{1}$ (Ministry of Education and Culture, 1996) contended that Israelis have a mostly passive concept of citizenship and risk reaching a state of imbalance between the value of "I deserve" and that of "the other deserves" (ibid.). In contrast, citizenship may also be perceived as an active and conscious state in which one assumes social environmental responsibility for one's community: "Citizenship, as empowering extensive activity in the social and political spheres, manifested in the capacity to take part in shaping the public domain" (ibid.). Civics is intended to deal with all these aspects.

In this respect, Dr. A. Carmon, chairman of the Israeli committee created recently by the Minister of Education in order to clarify the proper limits of discourse (cited in Leibovitz, 2014), said, "Civic studies are aimed at preparing each student to become actively integrated and to function in civil society according to his or her worldview; to be able to do this in a complex social-cultural-political reality, despite controversial issues. They should be prepared to accomplish this in accordance with the values of our society, with tolerance and respect for a wide spectrum of opinions [...]. (Civic studies) mean nourishing the capacity to conduct a proper discourse based on constant striving for consensus or compromise."

\section{Formal Civic Studies In Different Countries}

The nature of formal civic studies depends, to a large degree, on the definition and orientation embraced by each community. For example, in England citizenship is perceived as a social-moral responsibility, community involvement, and political literacy (Crick Report, 1998²). In order to help young people become such citizens, England operates a 4-stage civics program, covering all one's time in the public education system (ages 5-18), with the ultimate aim of creating active and involved citizens (Brownlie, 2001). On the other hand, in the United States the orientation is much less clear. Thus, a survey carried out in 1997 found that most states mandated or suggested civics curricula and policies while fewer states had curricula and policies addressing values education (Pederson \& Cogan, 2000). A recent survey carried out in 2010 uncovered a significant amount of pessimism among the public about whether high school students are actually learning much about citizenship in high school (Lautzenheiser et al., 2011).

The school, as a main agent of socialization and a system experienced by most residents, is one of the major tools of civic education. Civic studies, in this context, are all the more important due to their power to forge future citizens. In a democratic country, civic studies are closely affiliated with values education, and the instilling of both universal and national values forms a central goal of this discipline (Ichilov, 2001; Otsu, 2000; Thomas, 1990; Tse, 1997). One should bear in mind, however, that civic education teachers work in a field that is institutionally ill-defined and highly sensitive to the macro-political cultures of each nation and to the micro-political culture of schools within these nations (Ichilov, 2003; Mintrop, 2002; Schwille \& Amadeo, 2002).

\footnotetext{
${ }^{1}$ The Kremnitzer Committee: On March 15, 1995, the Minister of Education appointed a steering committee to develop a comprehensive scheme to teach schoolchildren civics, which would provide a foundation of values and conduct for all citizens of Israel to share. The committee was chaired by Professor Mordechai Kremnitzer of the Faculty of Law, The Hebrew University. To guide its consideration of the underlying principles for the scheme and to help in developing a tentative action plan, the committee was asked to address the following questions:

A. Which values of good citizenship and which citizenship skills should be encouraged in children during their school years?

B. Which values and skills should be taught at which school level?

C. What are the main approaches that schools can use to teach these values and skills at every level and how should this program fit in with the Civics course in junior high school?

D. What organizational framework/s can be used to promote the program to Israeli schools and how can the program be monitored and evaluated?

${ }^{2}$ The Crick Report is a White Paper composed by an advisory group appointed by the British Secretary of State for Education and Employment "to provide advice on effective education for citizenship in schools - to include the nature and practices of participation in democracy; the duties, responsibilities and rights of individuals as citizens; and the value to individuals and society of community activity."
} 
In Israel - a multicultural and deeply divided society where $75 \%$ of the population is Jewish and $21 \%$ Arab, the situation is especially complex. The rifts between Jews and Arabs, between fundamentalists and orthodox Jews on one side and secular Jews on the other, and between citizens with a left- and right-wing political orientation, are very deep (Ichilov, 2003; Pedahzur, 2004; Soen, 2003). Inculcating a shared civic identity capable of bridging social cleavages, where little consensus exists regarding fundamental issues, is an extremely difficult task indeed (Byrne, 1997; Ichilov, 1999, 2003).

The Israeli Ministry of Education sees values education as an important goal and 18 years ago even established a special team to promote and enhance ethics education (The Kremnitzer Committee). The research literature has so far focused mainly on examining the values of students in religious public schools (e.g., Arend, 2000; Dagan, 2003; Levy, 2002; Vaknin, 1999). The scant literature on students of secular public schools indicates that students particularly value personal happiness, family, military service, and helping others, while religious tradition is considered less important. Volunteer work in the IDF (Israel Defence Force) is considered more important than volunteer work in the community (Cohen, 2008).

In the current study, an attempt was made to expand existing research and focus on the issue of values among students in secular public schools (The Israeli education system is a three-partite one consisting of secular public schools [55.6\% of all elementary school students in 2013], religious public schools [19.2\% of all elementary school students in 2013], and private ultra-orthodox schools [25.2 \% of all elementary school students in 2013] CBS, 2013b, 403), and, specifically, civics instruction and education. The main purpose of this research is to outline the "basket of values" espoused by teenagers in formal and informal settings in an attempt to examine the relationship between national and Jewish values on the one hand and universal democratic values on the other, among secular Israeli teenagers in the post-modern era.

\section{Teaching Civics In Israel - Trends And Transitions}

Civics is currently an obligatory field of study in Israeli junior high and high schools. In high schools, it is taught for two years (in the 11th and 12th grades) for three hours a week and is part of the matriculation examinations. Israeli civic studies have experienced a series of transformations since the State of Israel was first established, reflecting the prevalent ethical atmosphere. Instruction of civics was perceived, even in pre-state years, as a tool for advancing national goals: [and] "to create a national pedagogy... so that they [the students] will become an instrument of redemption and a tool for realizing our historical mission" (Orinovsky, 1948, p. 59).

Nationalism and Judaism were stressed in all disciplines until 1953, when the State Education Law was enacted (State Education Law, 1953). The new law united contents taught in both secular and religious public education systems, with supplementary religious education for the religious system. (Thus, the religious public system allocates 47.6 weekly hours to religious studies in junior high schools versus 9.2 hours allocated in the secular public system [Resh \& Benavot, 2009, 43]). This ended the ideologically-based division of the education system introduced in 1949. This law led to depoliticization of the education system and to a weakening of national pedagogy. It was a landmark symbolizing initial recognition of the significance of universal elements - "To teach one to be a lover of human beings...". (Objective of the public education system, section 2(1), ibid.) Nevertheless, schools are allowed a great deal of flexibility and freedom to choose subjects for extended study in addition to mandatory core subjects. There is a huge difference between the curricula taught in the two systems. Thus, $86.2 \%$ of the public religious schools chose to teach an extended Bible program, 79.3\% chose to teach an extended Mishnah program, and $68.9 \%$ chose to teach an extended program in Jewish philosophy. Needless to say, public secular schools made completely different choices (Ayalon, 2000, Table 3).

The transition to a public education system had an effect on civic studies, which were also utilized to establish a specific political culture and civic tradition. Over the years, the role of nationalist education as a central axis of school subjects, in general, and of civic studies, in particular, gradually declined (Ichilov, 2001). This was even truer of the exclusion of Jewish studies (Zisenwein, 2003) and it is particularly evident in history classes which, over the years, have gradually tended more toward general history at the expense of Jewish history. The story of the State of Israel - once a central study topic - has been played down since the mid-1970s (Hoffman, 2002) until the reform initiated in 2009. 
This transformative trend reached its height in the 1980s and was manifested in a Director General Circular in 1985. At that time, the Ministry of Education stated that when in conflict between unique and universal values, the latter should be preferred, claiming that "civil rights based on the tenets of democracy and democratic processes have a decisive role and should guide our actions" (Ministry of Education Culture and Sports, 1985). This outlook reflected the transition to civic studies informed by the principles of democracy versus the formerly dominant national and Zionist dimensions. Some thought that the earlier approach lacked balance, particularly when faced by changes in the national order of priorities: "... While in Israel's first forty years, establishment of the state and its existential defense were top priority, in the twenty-first century, priority was increasingly given to individuals in Israeli society and their status" (Ministry of Education and Culture, 1996). The growing emphasis on individualism and individuals created a need for civic studies with a balance between the unique and the universal.

The Kremnitzer Committee, formed with the aim of designing civic studies as a common ethical and behavioral foundation of all citizens (ibid.), stated in its recommendations that the goal should be to teach multipurpose civic studies - "...internalization of Israel's values, creating a commitment to democratic government and readiness to defend it, the capacity and desire to be active, involved, and responsible citizens" (ibid., abbreviated interim report). Other goals should be to encourage engagement in fundamental issues pertaining to the nature of Israel as a Jewish democratic state and their implications for the relationship between Israel and Diaspora Jewry, for the relationship between religious and political affairs in Israel, and for the relationship between majority and minority groups in Israel.

While the Kremnitzer Committee referred to the diminishing of the Zionist dimension, the Shenhar Committee $^{3}$ reported that, in the secular public education system, the Jewish dimension had lost its clarity and had become engulfed by the national pluralistic culture (Ministry of Education and Culture, 1996). The committee appointed to examine the state of Jewish studies in the secular educational system stated that it would be advantageous to turn the schools into a "focal point for developing alternative options for a Jewish-Israeli cultural consciousness unaffiliated with Jewish legal authorities and in association with Jewish history and creativity from a variety of aspects incoporating criticism and innovation" (ibid., 6). Thus, civic studies in Israel seek to include all of these aspects - Jewish, national, and universal - to nurture one's civic identity side by side with one's national identity, to impart Jewish values side by side with democratic values, and to encourage pluralism and tolerance together with recognition of the State of Israel as a Jewish state (see objectives of the program on views, Ministry of Education Culture and Sports, 1996).

\section{The Significance Of The Transitions In Israeli Civic Studies}

All these developments should be viewed in light of Israel's demographic diversity. To begin with, as stated above, Israel is, for all intents and purposes, a bi-national state, with Arabs constituting $20.7 \%$ of the population and Jews $75.1 \%$ (CBS, 2013a). What is more, the Jewish population itself is very diverse. In 2012, $41.6 \%$ were Israeliborn, $32.1 \%$ were born in Europe or America, $11.4 \%$ were born in Asia, and $14.9 \%$ were born in Africa (CBS, 2013b, 110). Moreover, $11.2 \%$ of the Jewish population defined itself as ultra-orthodox (Haredi) in 2013, $9 \%$ as orthodox, $15.1 \%$ as observant-traditional, $13 \%$ as secular-traditional, and $49.1 \%$ as secular (Herman et al., 2013, 228).

Civic studies, in contrast to other academic subjects, are aimed at teaching students to become citizens in the widest meaning of the word. This is the only subject taught at school aimed, first and foremost, at imparting values. In other disciplines, acquiring knowledge and skills is the ultimate goal and instilling ethics is an added value. For example, primary goals of history studies are "learning about major historical events and understanding their significance as constitutive events in the history of Israel and the nations... [as well as] developing thinking strategies, capabilities, and skills necessary for learning history" (history curriculum for high schools in the religious public education system, 2010). Similarly, the ultimate goal of geography studies is "to construct a knowledge base and develop higher-order thinking skills" (compulsory curriculum in geography and environmental

\footnotetext{
${ }^{3}$ The Shenhar Committee was appointed by the Minister of Education on the $9^{\text {th }}$ of October, 1991, in order to report on the state of the Jewish studies in the Israeli secular school system. The committee was expected to study the contents of the Jewish studies, their frames, their fields of study, their teaching systems, and the system's organization.
} 
studies for high schools, 2008). This is also true of all other disciplines taught at school, which examine students' knowledge rather than their values.

Civic studies are unique for their clear ethical agenda, seeking to turn students into better citizens or, as stated by the Ministry of Education, "[to teach] good citizenship and rational involvement in the public life of a democratic Jewish state" (high school curriculum for Jewish, Arab, and Druze schools, 2002). As stated by the Kremnitzer Committee 18 years ago, the aim of civic studies is "to develop the capability to analyze complex social and political issues...to analize issues related to the tension between different human rights [...], the capacity to form a founded and reasoned criticism, the capacity to take part in a civil dialogue with others holding different opinions [...], and the capacity to understand, appreciate, and respect other cultures" (Leibovitz, 2014). Curricula reflect beliefs concerning the appropriate contents of children's studies in an educational setting and their justification (Alpert, 2002). This is also true of the civics curriculum. While in other disciplines, the goal is not necessarily that students should become historians, mathematicians, geographers, etc.; the purpose of studying civics is that students should become citizens in the full sense of the word; namely, "good citizens". Teaching good citizenship is deeply rooted in the field of values education. Last, but not least, in Israel, civics includes both knowledge of democracy, its history and tradition in the state, as well as citizenship; namely, the development of skills, attitudes, beliefs, and values for actively involving students in the society, culture, and democratic framework of the country.

\section{Education As The Imparting Of Values}

The concept of values, in general, refers to the nature and quality of people's behavior. This evaluation of behavior may take a wide variety of forms and some claim that these cannot be incorporated within a single concept accepted and recognized by all scholars (Albert, 1968). Support for this contention may be found in the widely divergent definitions of values. Some see values in how people evaluate their behavior over time - "beliefs held over time concerning a certain behavior, outcome, or final state preferred by an individual or by society" (Rokeach, 1973, p. 5). Others suggest that these are standards by which different courses of action are examined and selected (Smith, in: Friedman, 2001). Friedman (2001) refers to values as ideals in light of which life goals, experiences, and actions are considered. Whatever the preferred definition, everyone will agree that ethics and values have a positive meaning - something that should be maintained, as described by Y. Smilansky: "Values are... nice words. Everybody likes them, everybody is in their favor. Like peace, like hope, like children. Everybody knows that something is stopping them from being what they should be, like peace, like hope, like adults who emerge from children" (1983, p. 5). Despite the pessimism reflected in these words, educators believe and hope in their hearts that it is possible to help students to "be what they should be" or what their potential allows them to be. As the goal of education is "always to possess the student's soul through the spirit conveyed by the educator, and in the absence of such possession, there is no educational act" (Kaufman, 2005, p. 129).

Until 2009 - at least on a declarative level - civic studies in Israel were aimed at teaching a wide range of values. The Ministry of Education tried to create a blend of Jewish and national values; of democratic values and their implementation in practice; to teach students to recognize the significance of human rights, citizens, and minorities; to develop their sensitivity toward the weak and their defense; and to internalize values of pluralism and tolerance. In the current study, the authors sought to examine if and to what degree has the Ministry of Education succeeded in instilling these values.

\section{METHOD}

This study is designed to examine the values instilled in Israeli teens through civic studies within the Israeli historical model. The study made use of two instruments - a democratic attitudes questionnaire and a values questionnaire. The democratic attitudes questionnaire was taken from the Guttman Survey Center, which has been operating under the Israel Democratic Institute since 1998. The values questionnaire was developed by Masloveti and Iram (2002) and published in their book "Value education in diverse teaching contexts." This typology of values has also been suggested by other authors (e.g., Oron, 1993). Both questionnaires were tested and used time and again in Israel over the years. To these, the authors added an index of Holocaust memory and commemoration 
[tested and used in the authors' studies of Israeli trips to Holocaust sites in Poland (Davidovitch \& Soen, 2012)]. Students were requested to rate the importance of the values that were presented in six categories:

1. Values related to life in general (human dignity, sanctity of life, survivability, protection of family)

2. Jewish values (Torah, Jewish commandments, Judaism)

3. Zionist values (national pride, Zionism, immigration absorption, duty to and sense of unity with the Diaspora, security)

4. Social values (social equality, democracy, tolerance, concern for others)

5. Values related to achievements (one item)

6. Values related to Holocaust memory and commemoration (one item)

\section{Research Population}

The questionnaire was completed by 1,320 secular public school students in grades 11 and 12 . Participants were selected by random sampling based on a Ministry of Education list of all secular public schools in Israel. The questionnaire was also completed by 256 members of an Israeli youth movement - HaNoar HaOved VeHalomed found to be compatible in their background variables with the first group (see Table 1), with the aim of comparing the values of the two groups. The two research groups represent formal and informal youth settings.

The authors further sought information on whether the students are members of youth organizations, participate in leadership activities or in volunteer activities in the community and, if so, to what extent. As about 175,000 youngsters were members of a youth organization (or "youth movement" as it is known in Israel) in 2006, the authors decided to examine whether youth group members constitute a distinct group in terms of their values. The authors selected the HaNoar HaOved VeHalomed youth group as representative of other similar groups. This group is the largest of its kind in Israel and its values, which emphasize civic values, were deemed suitable for a study focusing on this topic. Table 1 presents the background data of the participants (the majority of participants were male and secular).

Table 1: Background Information On Participating Students And Youth Group Members

\begin{tabular}{cccc}
\hline & & Students Grades 11 And 12 & Youth Group Members \\
\hline Variable & Category & $\mathrm{N}=1,320$ & $\mathrm{~N}=256$ \\
\hline \multirow{2}{*}{ Sex } & Male & $\% 61$ & $\% 62$ \\
& Female & $\% 39$ & $\% 38$ \\
\hline \multirow{2}{*}{ Religiosity } & Observant & $\% 1$ & $0 \% 25$ \\
& Traditional & $\% 30$ & $\% 75$ \\
\hline
\end{tabular}

\section{Research Procedure}

An attitude survey, which was anonymous, was distributed to all teenagers for self-completion during activities at school or in the youth group and took about 30 minutes to complete. A research representative was present at the questionnaires' administration. Questionnaires contained 16 items related to attitudes, ranging from individual to Jewish to national and to universal values. Participants rated the importance they attributed to each value on a Likert-type scale from 1 (unimportant) to 5 (extremely important). Findings are presented either as the percentage of those who defined the values as Important (4) or Extremely important (5), or as rated on the Likert scale.

\section{DATA ANALYSIS AND METHODOLOGICAL COMMENTS}

Several measures of the major topics presented in the questionnaires were formed. The measures were constructed based on factor analysis and their quality was examined by calculating reliabilities ( $\alpha$ Cronbach):

1. Jewish values $(\alpha=.81)$

2. National Zionist values $(\alpha=.73)$

3. Universal values $(\alpha=.72)$ 


\section{Validation And Analysis}

Validity of the research instruments was examined using principal axis factoring, as the purpose of the analysis was to identify interpretable structures in order to explain connections between variables rather than to reduce the number of variables (Preacher \& Hayes, 2004). No significant correlations were found between the significance attributed by students to values and students' background variables (gender, religiosity, or age). This may be attributed to the fact that values cross gender and sectarian boundaries; age differences between the eleventh and twelfth grades are apparently not significant for students' value perceptions. The findings relating to the five categories first mentioned are included in Table 2.

Table 2: Survey Measures

\begin{tabular}{|c|c|c|c|c|}
\hline Measures & Mean & SD & $\mathbf{N}$ & $\alpha$ Cronbach \\
\hline Values Related To Life & 4.55 & 0.63 & 5,235 & 0.78 \\
\hline \multicolumn{5}{|l|}{ Human dignity } \\
\hline \multicolumn{5}{|l|}{ Sanctity of life } \\
\hline \multicolumn{5}{|l|}{ Survivabilty } \\
\hline \multicolumn{5}{|l|}{ Protection of the family } \\
\hline Values Related To Judaism & 4.01 & 1.12 & 5,225 & 0.87 \\
\hline \multicolumn{5}{|l|}{ Torah and commandments } \\
\hline \multicolumn{5}{|l|}{ Judaism } \\
\hline Values Related To Zionism & 4.22 & 0.73 & 5,230 & 0.81 \\
\hline \multicolumn{5}{|l|}{ National pride } \\
\hline \multicolumn{5}{|l|}{ Zionism } \\
\hline \multicolumn{5}{|l|}{ Immigration absorption } \\
\hline \multicolumn{5}{|l|}{ Obligation to Jews in the Diaspora } \\
\hline \multicolumn{5}{|l|}{ Security } \\
\hline Social Values & 4.40 & 0.70 & 5,235 & 0.81 \\
\hline \multicolumn{5}{|l|}{ Social equality } \\
\hline \multicolumn{5}{|l|}{ Democracy } \\
\hline \multicolumn{5}{|l|}{ Tolerance } \\
\hline \multicolumn{5}{|l|}{ Concern for others } \\
\hline Values Related To Achievement Seeking & 4.13 & 0.96 & 5,167 & - \\
\hline Values Related To Holocaust Memory And Commemoration & 4.53 & 0.82 & 5,199 & - \\
\hline
\end{tabular}

\section{FINDINGS}

As far as social values were concerned, a great deal of importance was attributed to democratic attitudes. Items were divided into two groups - democratic values (i.e.,. protecting democratic principles is a supreme value, all people have the same rights, minorities have the right to take action and demonstrate, etc.) and non-democratic values (i.e., during a crisis a strong individual is preferable as a leader in order to maintain law and order; discipline is more important than individual liberties, etc.).

As expected, in some aspects the findings revealed substantive differences between the two groups. Ratings by the youth movement members indicate a very high degree of commitment to democratic principles, including sensitivity toward minority groups, something that is not to be taken for granted considering local tensions and conflicts. Ratings also indicated openness to political pluralism. The highest rate of agreement in this group was for the opinion, "It is always important to protect democratic principles in the country" (97\% as compared to $82 \%$ among high school students). The value with the second highest rate of agreement (90\%) among youth movement respondents was, "All persons should have the same rights under the law, independent of their political position" (compared to $84 \%$ among high school students). The democratic value with which participants agreed least was "Even people and groups holding extreme positions should enjoy freedom of speech" ( $49 \%$ among youth group members versus $42 \%$ among high school students). These figures reflect participants' vacillation between freedom of expression and the duty to protect democracy against the threat of radicalism. 
Particularly conspicuous is youth movement members' negligible support for the two final values in Table 3 , which are negative by nature. A question onto itself is what preceded what, and why - "did participants who have a deep sense of civics join youth groups, or do youth groups manage to instill a deep sense of civics in their members?" Table 4 presents the significance that youth group members attributed to Jewish/Zionist, universal, and individual values.

Table 3: Participants' Attitudes To Democratic And Non-Democratic Values

\begin{tabular}{|c|c|c|c|c|c|c|c|c|}
\hline & \multicolumn{4}{|c|}{ Youth Movement Members } & \multicolumn{4}{|c|}{ High School Students } \\
\hline & $\mathbf{N}$ & Mean & Sd & $\begin{array}{c}\text { Rate Of } \\
\text { Agreement }\end{array}$ & $\mathbf{N}$ & Mean & Sd & $\begin{array}{c}\text { Rate Of } \\
\text { Agreement }\end{array}$ \\
\hline $\begin{array}{l}\text { It is always important to protect } \\
\text { democratic principles in the country. }\end{array}$ & 223 & 4.77 & 0.54 & $\% 97$ & 1,320 & 4.27 & 0.88 & $\% 82$ \\
\hline $\begin{array}{l}\text { All persons should have the same rights } \\
\text { under the law, independent of their } \\
\text { political position. }\end{array}$ & 219 & 4.53 & 0.92 & $\% 90$ & 1,320 & 4.37 & 0.90 & $\% 84$ \\
\hline $\begin{array}{l}\text { Minority groups should be allowed to } \\
\text { take action and demonstrate in order to } \\
\text { convince the majority. }\end{array}$ & 219 & 4.11 & 1.04 & $\% 77$ & 1,320 & 3.96 & 1.01 & $\% 68$ \\
\hline $\begin{array}{l}\text { The State of Israel belongs to all its } \\
\text { citizens. }\end{array}$ & 222 & 4.06 & 1.01 & $\% 75$ & 1,320 & 3.19 & 1.35 & $\% 44$ \\
\hline $\begin{array}{l}\text { Even people and groups with extreme } \\
\text { positions should enjoy freedom of speech. }\end{array}$ & 221 & 3.42 & 1.25 & $\% 49$ & 1,320 & 3.27 & 1.20 & $\% 42$ \\
\hline $\begin{array}{l}\text { Internal disputes could cause a rupture in } \\
\text { the nation. }\end{array}$ & 220 & 3.31 & 1.13 & $\% 45$ & 1,320 & 2.60 & 1.25 & $\% 23$ \\
\hline $\begin{array}{l}\text { During a crisis, a strong individual is } \\
\text { needed to maintain order. }\end{array}$ & 225 & 2.68 & 1.34 & $\% 26$ & 1,320 & 3.27 & 1.25 & $\% 47$ \\
\hline $\begin{array}{l}\text { Law, order, and discipline are more } \\
\text { important than individual liberties. }\end{array}$ & 221 & 1.95 & 1.22 & $\% 14$ & 1,320 & 2.40 & 1.28 & $\% 20$ \\
\hline
\end{tabular}

Table 4 indicates that the values accepted by almost all respondents (at least on the declarative level) are universal and individual values - human dignity (97\% and 95\% of the respondents, respectively), tolerance $(97 \%$ and $90 \%$ of the respondents), social equality (96\% and $91 \%$ of the respondents), sancity of life and democracy (95\% and $93 \%$ among of respondents), concern for others (93\% and $92 \%$ of respondents), protection of the family (90\% and $95 \%$ of the respondents), and security ( $89 \%$ and $94 \%$ of the respondents). Of the values related to Judaism and Zionism, the strongest agreement was associated with the following values: Holocaust memory and commemoration ( $92 \%$ and $94 \%$ of the respondents), Zionism ( $83 \%$ and $82 \%$ of the respondents), followed by immigration absorption (79\% of the respondents). The least agreement was associated with the value of national pride $(63 \%$ and $86 \%$ of the respondents). The value that received the weakest agreement was Torah and commandments (26\% and 54\% of the respondents). Notably, for high school students, the values topping their list of priorities were living life in general (human existence as a value) and personal realization (95\%), followed by Zionism (84\%), while Jewish values were at the bottom of the list (65\%). It should be noted that gender, as mentioned, had no impact at all on these results. 
Table 4: Participants' Attitudes Towards Universal, Jewish-Zionist, And Individual Values

\begin{tabular}{|c|c|c|c|c|c|c|c|c|}
\hline & \multicolumn{4}{|c|}{ Youth Movement Members } & \multicolumn{4}{|c|}{ High School Students } \\
\hline & $\mathbf{N}$ & Mean & SD & $\begin{array}{c}\text { Rate Of } \\
\text { Agreement }\end{array}$ & $\mathbf{N}$ & Mean & SD & $\begin{array}{c}\text { Rate Of } \\
\text { Agreement }\end{array}$ \\
\hline \multicolumn{9}{|l|}{ Universal Values } \\
\hline Human dignity & 219 & 4.77 & 0.50 & $97 \%$ & 1320 & 4.71 & 0.66 & $95 \%$ \\
\hline Tolerance & 218 & 4.65 & 0.59 & $97 \%$ & 1320 & 4.54 & 0.73 & $90 \%$ \\
\hline Social equality & 220 & 4.70 & 0.58 & $96 \%$ & 1320 & 4.55 & 0.73 & $91 \%$ \\
\hline Democracy & 220 & 4.73 & 0.63 & $95 \%$ & 1320 & 4.49 & 0.75 & $90 \%$ \\
\hline Sanctity of life & 218 & 4.76 & 0.53 & $95 \%$ & 1320 & 4.65 & 0.65 & $93 \%$ \\
\hline Concern for others & 217 & 4.59 & 0.71 & $93 \%$ & 1320 & 4.58 & 0.72 & $92 \%$ \\
\hline \multicolumn{9}{|l|}{ Jewish And Zionism Values } \\
\hline Holocaust commemoration and memory & 217 & 4.59 & 0.4 & $92 \%$ & 1320 & 4.72 & 0.61 & $94 \%$ \\
\hline Zionist & 219 & 4.37 & 0.82 & $83 \%$ & 1320 & 4.31 & 0.92 & $82 \%$ \\
\hline Immigration absorption & 218 & 4.20 & 0.90 & $79 \%$ & 1320 & 4.19 & 0.92 & $79 \%$ \\
\hline National pride & 220 & 3.8 & 1.10 & $63 \%$ & 1320 & 4.46 & 0.85 & $86 \%$ \\
\hline Obligation to the diaspora & 217 & 3.79 & 1.03 & $62 \%$ & 1320 & 3.99 & 1.00 & $70 \%$ \\
\hline Judaism & 218 & 3.52 & 1.14 & $53 \%$ & 1320 & 4.13 & 1.02 & $74 \%$ \\
\hline Torah and commandments & 219 & 2.60 & 1.28 & $26 \%$ & 1320 & 3.56 & 1.28 & $54 \%$ \\
\hline \multicolumn{9}{|l|}{ Individual Values } \\
\hline Protection of the family & 216 & 4.59 & 0.66 & $90 \%$ & 1320 & 4.78 & 0.58 & $95 \%$ \\
\hline Security & 218 & 4.46 & 0.77 & $89 \%$ & 1320 & 4.66 & 0.65 & $94 \%$ \\
\hline Survivability & 214 & 3.76 & 1.09 & $58 \%$ & 1320 & 4.33 & 0.86 & $83 \%$ \\
\hline Achievement seeking & 217 & 3.66 & 2.84 & $50 \%$ & 1320 & 4.17 & 0.91 & $77 \%$ \\
\hline
\end{tabular}

\section{SUMMARY OF FINDINGS}

- Jewish-Zionist values: Most high school students and youth movement members attribute significance to these values.

- $\quad$ Social-individual values: Almost all high school students and youth movement members attribute great significance to these values.

- Democratic values: Almost all high school students and youth movement members attribute great significance to these values.

- $\quad$ Attitudes toward democracy in practice: The vast majority of high school students and youth group members believe that democratic values should always be protected, all people deserve the same rights, minority groups should be allowed to demonstrate to convince the majority. As mentioned above, the commitment of youth movement members to democracy is, in fact, much deeper than that of the other group. A conspicuously small proportion of youth movement members support the "non-democratic" values of the need for a strong leader and maintenance of law and order.

- $\quad$ Summary of values, according to significance: Jewish-Zionist values received the lowest ratings of all values. The difference between the importance attributed by youth movement members to democratic values, on the one hand, and to Jewish and religious values on the other, was 30\%-40\%.

\section{DISCUSSION}

Since establishment of the State of Israel, Israeli society has consisted of a melting pot of different identities and Diasporas and is constantly struggling to assert its character and leading values. The education system, in all its variety discussed in this article, reflects a cultural crisis manifested in what is sometimes alluded to as the diminution of knowledge concerning Judaism and nationalism. Milestones in the development of civic studies in the period covered by the article indicate the increasing tendency toward teaching universal fundamental values, where Jewish and Zionist values should stem from the wide perception of these values that shape the new educational concept of ethics education. 
The education system which, at first, gave top priority to consciously becoming part of the Israeli milieu and preserving Jewish heritage, later changed; it became more diverse and developed its perception of ethical priorities. The trend in civic studies has been to encourage general behavioral pluralistic views on the humanistic level. The findings can be interpreted in two ways - the hierarchic outlook and the complementary worldview.

\section{Hierarchic Outlook}

The first option is to embrace a hierarchic outlook, whereby results are analyzed as existing on a hierarchy of values with significance accorded by ordinal ranking, in which values located lower on the hierarchy have less significance. Utilizing this approach for analyzing findings explains the ethical mix in terms of significance; i.e., higher means more meaningful and important. From this perspective, the values' hierarchy of Israeli high school students is composed of universal values at the top of the pyramid (93\%) followed by human dignity, sanctity of life (democratic values), capacity to survive, family preservation, side by side with self realization (90\%) (individualist values). Zionist values (as part of the national values) come in third (81\%) and Jewish values (perhaps because they were interpreted by some members of the sample as religious values, while others interpreted them as national values) are at the bottom of the list (63\%).

These findings are reminiscent of those of Cohen (2008) who revealed the high significance of dimensions of happiness and self realization and the lower significance of values related to Judaism. An almost identical hierarchy was also found among youth movement members; this, in contrast to the prevalent belief that they constitute a distinctive select population. From an ethical standpoint, they display similar ordinal inclinations.

The hierarchic approach, which perceives value priority as central, shows that civic studies have managed to realize one of their declared goals - instilling universal values in students. The significance attributed to the order of values shows that universal values come at the expense of Jewish and Zionist values, which have a lower place in students' ethical world. The hierarchy that emerges is explained by the fact that the education system does integrate Jewish and Zionist elements throughout the school year by marking Jewish holidays, ceremonies of remembrance and commemoration, independence celebrations, and many informal events.

However, despite these extensive activities, students have no solid knowledge base resembling that created when studying the universal aspects of civics. Students in Israel's secular public education system were instructed (until the 2009 reform) on becoming citizens of the world - on skills and capabilities necessary for living in a global, secular world. National, and specifically Jewish principles, were constantly in the background but did not receive the same amount of didactic attention. For example, in history lessons, Jewish and Israeli history has been receiving gradually less attention, leading to the dimming of both the Jewish and Israeli narratives (Hoffman \& Shanel, 2002). Civic studies, which seek to instill Jewish and national values as well as universal values, cannot ignore their context in which different disciplines teach students to see the world through a "universal prism", making it difficult for them to attribute proper meaning to national aspects. Students studying in a post-modern secular world learn to examine their surroundings in western terms, emphasizing democratic aspects but not leaving much room for national and religious contexts. For this reason, one might accordingly say that civic studies (at least until the 2009 reform, which changed this pattern but is beyond the scope of this paper) were somewhat deficient in their attempt to cope with their most significant challenge - to create citizens who are, first and foremost, citizens of Israel, even before they are citizens of the world.

\section{Complementary Worldview}

In contrast to the above, according to the complementary worldview - which awards values absolute rather than relative significance, Israeli students had clearly assimilated the intended values to different degrees at the time of the survey. Universalism, self realization, Judaism, and Zionism were values that received significance in the lives of teenagers from an absolute perspective, as they perceived themselves as both Israelis, Jews, and citizens of the world. The complementary approach - linking human love, peace, and Torah - exists in the Jewish worldview as well, as formulated by Hillel the Elder: "loving peace and pursuing peace, loving your fellow creatures and bringing them close to the Torah" (Mishna Avot 1:12). Thus, traditionally, Judaism accepts - and even encourages - such an ethical mix in which courtesy receives priority over Torah (Tana Devey Eliahu, Chapter 10). In this reciprocal 
approach, the various ethical elements are not distinct, as it is written: "Where there is no Torah, there is no culture; and where there is no culture, there is no Torah" (Mishna Avot 3:17). If one chooses to examine the current state of affairs from this perspective, one will discover that the values evident among teenagers are compatible with those that civic studies seek to instill, and the issue of proportions is debatable. Would we like Zionist values to be more dominant than democratic values? Would we like to reinforce Jewish values and bring them closer to Zionist values? To change the proportions, policy makers must make corresponding changes in the curriculum. As for the situation at the time of the survey, the value mix produced by civic studies resembled the intended proportions for universalism, Zionism, and Judaism.

One final word: Ratings of the youth movement members in the survey indicated a very high - higher than that of the high school students - commitment to democratic principles, including sensitivity toward minority groups (Table 3). A question onto itself is "what preceded what and why did participants, who have a deep sense of civics, tend to join youth movements, or did youth movements manage to instill a deeper sense of civics in their members?"

\section{AUTHOR INFORMATION}

Professor Nitza Davidovitch serves in teaching and administrative positions at the Ariel University Center. She is currently the Director of Academic Development \& Evaluation. Her areas of research interest include academic curriculum development, development of academic instruction, Holocaust awareness and Jewish identity, student exchange programs with Germany and Poland, preservation of the heritage of Jewish sects, and moral education.

Professor Dan Soen earned his B.A. in Oriental Studies at The Hebrew University, Jerusalem, in 1955. He earned his PhD at Vienna University, 1959, in Cultural Anthropology. He has taught in various universities in Israel and abroad (New Zealand, South Africa, and the United States) and has headed various departments in numerous academic institutions. He has headed several research institutions and published approximately 30 books and 120 articles on social issues in Israel and abroad. Soen currently heads the Department of Sociology \& Anthropology and is Chair of the Dual Major Department at the Ariel University Center, Israel. He is also a professor at the Graduate School, Kibbutzim School of Education in Tel Aviv.

\section{REFERENCES}

1. Albert, E. M. (1968). Value systems. In D. L. Sills (ed.), International Encyclopaedia of the Social Sciences 7 (pp. 287-291). New York: Macmillan.

2. Alpert, B. (2002). Introduction: Concepts and ideas in curricula as guiding texts. In A. Hoffmann and Y. Shanel (eds.) Objectives and Values in Curricula in Israel (pp. 9-29). Even-Yehuda: Rechess [Hebrew].

3. Arend, M. (2000). Jewish Education in an Open Society, Ramat Gan [Hebrew].

4. Ayalon, H. (2000). Table adapted from the Central Bureau of Statistics, presented at an inter-university meeting on curriculum.

5. Brownlie, A. (2001). Citizenship education: The global dimension, guidance for key stages 3 and 4 . London: Development Education Association.

6. Byrne, S. (1997). Growing up in a divided society: The influence of conflict on Belfast schoolchildren. Teaneck, NJ: Fairleigh Dickinson University Press.

7. Cairns, A. C. (1999). Introduction. In A.C. Cairns, J. C. Courtney, P. MacKinnon, H. J. Michelmann, \& D. E. Smith (Eds.). Citizenship diversity and pluralism: Canadian and comparative perspectives. Montreal, McGill-Queens University Press.

8. $\quad$ CBS (Central Bureau of Statistics). (2013a). Press Communique 243/2013. Jerusalem.

9. $\quad$ CBS (Central Bureau of Statistics). (2013b). Statistical Abstract of Israel 2013, 64. Jerusalem.

10. Cohen, E. (2008). Jewish Identity Values and Leisure of Israeli Youth. Tel Aviv: Tel Aviv University, School of Education, The Kelman Center [Hebrew].

11. Crick Report. (1998). Education for citizenship and the teaching of democracy in schools - Final report of the Advisory Group on Citizenship. London: Ministry of Education and Empolyment.

12. Dagan, M. (2003). Forging the world of values of religious students in the struggle against post-modernism. Shma'atin, 151, 145-157 [Hebrew].

13. Davidovitch, N., \& Soen, D. (eds.). (2012). The Holocaust ethos in the $21^{\text {st }}$ Century: dilemmas and 
challenges. Krakow and Budapest: Austeria Publishing House.

14. Friedman, A. (2001). Motivating values at the school. Reviews in Educational Administration and Organization, 25, 7-39 [Hebrew].

15. Gilbert, R. (1996). Studying society and environment. Melbourne: Jacaranda.

16. Hannam, D. (1999). Schools for democracy: From rhetoric to reality. Connect, 118 (August).

17. Heather, D. B. (1990). Citizenship: the Civic Ideal in world history, politics and education. London, Palgrave Macmillan.

18. Herman, T., Heller, E., Atmor, N., \& Lebel, Y. (2013). Israel's democracy index 2013. Jerusalem: Israel Institute of Democracy (Hebrew).

19. High school curriculum for Jewish (secular and religious), Arab, and Druze schools. (2002). Accessed on 11 April 2011 at the website of the Ministry of Education, Division for Study Planning and Development: http://cms.education.gov.il/EducationCMS/Units/Tochniyot_Limudim/Portal/TochniyotLimudim/CativaEl yuna/Ezrachut.htm [Hebrew].

20. History curriculum for state religious high schools. (2010). Accessed on 11 April 2011 at the website of the Division for Study Planning and Development:

http://cms.education.gov.il/educationcms/units/tochniyot_limudim/portal [Hebrew].

21. Hoffman, A. (2002). Between national history and general history: Values and goals in history curricula 1956-1995. In: A. Hoffmann and Y. Shanel (eds.). Objectives and Values in Curricula in Israel. EvenYehuda: Rechess, 131-159 [Hebrew].

22. Hoffmann, A., \& Shanel, Y. (eds.). (2002). Objectives and values in curricula in Israel. Even-Yehuda: Rechess, Introduction [Hebrew].

23. Ichilov, O. (1990). Political socialization, citizenship, education and democracy. New York: Teachers College Press.

24. Ichilov, O. (1999). Citizenship in a divided society: The case of Israel. In J. Torney-Purta, J. Schwille \& J. A. Amadeo (eds.): Civic education across countries: Twenty-four national case studies from the IEA civic education project, pp. 371-394. Amsterdam:IEA.

25. Ichilov, O. (2001). Civic education in a changing world: Global and Israeli trends. Y. Iram, S. Scolnicov, J. Cohen, \& E. Schachter (eds). Crossroads: Values and Education in Israeli Society. Jerusalem: Ministry of Education [Hebrew].

26. Ichilov, O. (2003). Teaching civics in a divided society: The case of Israel. International Studies in Sociology of Education, 13, 3: 219-241.

27. Kaufman, Y. (2005). Instilling values and assimilating reverence: Education as cultural possession of the student's soul. In: N. Aloni (ed.), All a man should be: A philosophical educational journey. Tel Aviv, Hakibbutz Hame'uhad and Machon Mofet, 129-131 [Hebrew].

28. Lautzenheiser, D. K., Kelly, A. P., \& Miller, C. (2011). Contested curriculum: How teachers and citizens view civics education. Policy Brief 1. Washinghton DC: American Enterprise Institute for Public Policy Research.

29. Leibovitz, E. (2014). To take the dusty report off the shelf. Haaretz, February 24, p. 15 [Hebrew].

30. Levy, S. (2002). Similarities and differences in the value system of two generations of Israeli youth (1974 and 1994) of the general and religious educational systems. In: A. Hoffmann and Y. Shanel (eds.). Objectives and Values in Curricula in Israel. Even-Yehuda: Rechess, 179-200 [Hebrew].

31. Marshall, T. H. (1952). Citizenship and social class. Cambridge, Cambridge University Press.

32. Metzer, D., \& Rosen, N. (2009). Civic studies in the curricula of five selected countries. Ministry of Education, Pedagogic Office, Division of Curricula Planning and Development [Hebrew].

33. Ministry of Education and Culture. (1985). Special circular - "Teaching democracy" [Hebrew].

34. Ministry of Education and Culture. (1996). Being citizens: Civic studies for all Israeli students. Kremnitzer Committee Report [Hebrew].

35. Mintrop, H. (2002). Teachers and civic education instruction in cross-national comparisons. In G. StinerKhamsi, J. Torney-Purta, \& J. Schwille (eds.). New paradigms and recurring paradoxes in education for citizenship: An international comparison (pp. 61-85). Amsterdam: JAI Press.

36. Mishna, Avot [Hebrew].

37. Orinovsky, A. (1948). What is Zionist education? Shorashim, III [Hebrew].

38. Oron, Y. (1993).

39. Otsu, K. (2000). Civics education in Japan: Values promoted in school curriculum. Asia Pacific Journal of 
Education, 20, 1, 73-81.

40. Pedahzur, A. (2004). The structural paradox of civic education in Israel. Megamoth, 43, 1, 64-83 [Hebrew].

41. Pederson, P. V., \& Cogan, J. J. (2000). Civics and values education curriculum policies in the United States: A survey of the states. Asia Pacific Journal of Education, 20, 1, 93-105.

42. Preacher, K. J., \& Hayes, A. F. (2004). SPSS and SAS procedures for estimating indirect effects in simple mediation models. Behavior Research Methods, Instruments, \& Computers, 36, $717-$

43. Prior, W. (1999). Teachers, students and their parents talk about what it means to be 'a good citizen' in Australia. Theory \& Research in Social Education, NCSS, Spring, 27:2.

44. Prior, W. (2006). Civics and citizenship education. Ethos, 14, 4, 6-10.

45. Resh, N., \& Benavot, A. (2009). What is actually being taught in schools? Diversity and uniformity in the implementation of the official curriculum in Israeli junior-high schools. Megamot, 43, 1: 7-76. (Hebrew).

46. $\quad$ Rokeach, M. (1973). The Nature of Human Values. New York: Free Press.

47. Schwille, J., \& Amadeo, J. A. (2002). The paradoxical situation of civic education in schools: Ubiquitous and yet elusive. In G. Stiner-Khamsi, J. Torney-Purta \& J. Schwille (eds.), New paradigms and recurring paradoxes in education for citizenship: An international comparison (pp. 105-137). Amsterdam: JAI Press.

48. Shenhar and Kremnitzer Team. Accessed on 13 May 2011 at: http://cms.education.gov.il/EducationCMS/Units/Haifa/ChevraPrat/Mate/ [Hebrew].

49. Smilansky, J. (1974). On education and the teaching of values. Tel Aviv: Am Oved - Culture and Education [Hebrew].

50. Soen, D. (2003). Land of rage and fury: Cleavages and identity in Israel. Qiriat Bialik: Ach Publishing House [Hebrew].

51. State Education Law. (1953). [Hebrew].

52. The Kremnitzer Report. (1996). Full version of the Report, Internet: cms.education.gov.il/EducationCMS/Units/OWL/English/Pedagogic/Being/ Accessed: 4.11.2013.

53. Tana Devey Eliahu, Mishna. Chapter 10.

54. Thomas, M. (1990). Applying a patriotism textbook-rating device: An Indonesian example. In Educational Research Quarterly, 12, 4, 42-56.

55. Tse, K. C. (1997). The poverty of political education in Hong Kong secondary schools. Hong Kong: Hong Kong Institute of Asia-Pacific Studies, The Chinese University of Hong Kong.

56. Vaknin, R. (1999). On the issue of teaching ethics in the state religious education system. Lizvulun, Jerusalem, 238-240 [Hebrew].

57. Zisenwein, D. (2003). Jewish education policy in Israel from the pre-state era to the present, in: Y. Dror, D. Nevo, \& R. Shapira (eds.). Turns and returns in Israeli education: Policy guidelines for the 2000s (151161). Tel Aviv: Ramot [Hebrew]. 


\section{NOTES}

